九州大学学術情報リポジトリ

Kyushu University Institutional Repository

Effects of Seeding Date and Cultivars on Yield and Growth Characteristics of Sorghum $X$ Sudangrass Hybrid [Sorghum bicolor (L.) Moench] Cultivars in Central Region of South Korea

JUNG, Sung, Jeong

Grassland \& Forage Division, National Institute of Animal Science

CHO, Jin-Woong

Department of Crop Science, Collage of Agricultural and Life Sciences Chungnam National University

YAMAKAWA, Takeo

Laboratory of Plant Nutrition, Division of Molecular Biosciences, Department of Biosciences \& Biotechnology, Faculty of Agriculture, Kyushu University

https://doi.org/10.5109/2339057

出版情報: 九州大学大学院農学研究院紀要. 64 (2)，pp.191-198，2019-09-02. Faculty of Agriculture, Kyushu University

バージョン：

権利関係 : 


\title{
Effects of Seeding Date and Cultivars on Yield and Growth Characteristics of Sorghum x Sudangrass Hybrid [Sorghum bicolor (L.) Moench] Cultivars in Central Region of South Korea
}

\author{
Jeong Sung JUNG ${ }^{1}$, Jin-Woong $\mathrm{CHO}^{2 *}$ and Takeo YAMAKAWA ${ }^{3}$ \\ Laboratory of Plant Nutrition, Division of Molecular Biosciences, Department of Biosciences \& Biotechnology, \\ Faculty of Agriculture, Kyushu University, 744 Motooka, Nishiku, Fukuoka 819-0395, Japan \\ (Received April 23, 2019 and accepted May 8, 2019)
}

\begin{abstract}
Changing temperatures is one of the major threats to the maintenance of plant yield. Shifting the planting date is the best way to cope with climate change. The aim of this experiment was to determine optimum seeding dates for sorghum $\times$ sudangrass hybrid $(\mathrm{SSH})$ cultivars that can provide foundational information to develop improved forage cropping system in central reign of South Korea (CRSK). Three SSHs (Jumbo, Sordan 79 and Revolution) were seeded at four planting dates between April 20 and June 20 (April 20, May 10, May 30 and June 20), respectively. The growing period from the planting to the heading stages was shorter for the cultivars planted on May 10 and longest for those planted on April 20, while those seeded on June 20 could be harvested only once due to the short growing period. Plant height, stem diameter, leaf number, and sugar content were high in the cultivars planted on April 20 and May 10. Among the three cultivars, Jumbo was significantly taller with a large stem diameter, while Revolution was the shortest with a small stem diameter. The highest sugar content was found in Revolution and the lowest in Jumbo. During the 2-year average, the total dry matter yield from the cultivars seeding on April 20 was approximately 54\% higher than that of June 20. Additionally, it was difficult to apply seeding on April 20 in the double-cropping system with winter forage because of the prolonged growing period. Based on the yield and agronomic characters observed in this study, seeding on May 10 was ideal for developing improved forage cropping system in CRSK.
\end{abstract}

Key words: Central Korea, Cultivar, Seeding date, Sorghum $\times$ sudangrass, Yield.

\section{INTRODUCTION}

Agriculture is an important sector for the economy of a country. Agriculture and crop production are dependent on specific climate conditions. The mean temperature of Korea is continually increasing by approximately $1.7^{\circ} \mathrm{C}$, while global temperatures have risen by approximately $0.85^{\circ} \mathrm{C}$ according to the Climate change report 2014 (Kang 2015; Pachauri et al., 2014). Increasing temperatures reduce the growth and yield of several crops such as rice, barley, and soybean, which are greatly affected by changing climates. Climate change may cause an increase in the competition from weeds and lead to an expansion of pathogens, pests, insects and other factors in the crop agro-ecosystem (Kim et al., 2013; Son et al., 2009). Therefore, it is imperative to apply new cropping systems in distinct growing seasons (Jung et al., 2012) and sustainable cropping approach would be beneficial to farmers for increased crop yield and quality in the changing climatic conditions (Laucer et al.. 1999).

Temperature is one of the most important factors for growth and development in plants. According to a previ-

\footnotetext{
Grassland \& Forage Division, National Institute of Animal Science, Cheonan, Korea

2 Department of Crop Science, Collage of Agricultural and Life Sciences Chungnam National University, Daejeon, Korea

Laboratory of Plant Nutrition, Division of Molecular Biosciences, Department of Biosciences \& Biotechnology, Faculty of Agriculture, Kyushu University, 744 Motooka, Nishiku, Fukuoka 819-0395, Japan

* Corresponding author (e-mail: jwcho@cnu.ac.kr)
}

ous report, plant yield reduced significantly due to the variation in the sowing dates of plants (Pale et al., 2003). Early sowing at soil temperatures above $15^{\circ} \mathrm{C}$ is recommended for sowing sorghum $\times$ sudangrass hybrid (SSH) (Eastin 1976; Lee et al., 1997). However, it is also imperative to develop adequate cropping system for the supply and improvement of forage (Park et al., 2011). The qualitative and quantitative yield in forage plants may be influenced by cropping systems as well as intended applications as silage, hay and in soiling (Lee 2005). Therefore, suitable strategies, including land availability, cultivation management, soil fertility and irrigation facilities should be considered as potential factors to develop specific and effective cropping systems.

$\mathrm{SSH}$ is warm season grass and grows well under relatively high temperature, shows better tolerance to multiple stresses including drought, heat, salinity and flooding (Andy, 2008; Ejeta and Knoll, 2007; Schittenhelm and Schroetter, 2013). SSH is one of the most important forage cultivars (Seo et al., 1983). It is a suitable source for biomass production, weed suppression and nematode control. SSH is a good source of hay, silage, or green chop and is widely used for silage in Korea (Kim et al., 2009). It fits well to crop rotation systems associated with winter crops such as Italian ryegrass, forage barley, rye (Ji et al., 2010; Yoana et al., 2010) and Park et al. (2011) established SSH + rye + red clover as a good forage cropping system in CRSK field soil conditions.

The performance of sudangrass, sudangrass hybrids and SSH have been widely studied in CRSK. The 'Sordan 79' hybrid is one of the good SSH cultivars widely cultivated in CRSK because of the high yield, 
Table 1. Chemical properties of the soil before experiment during growing seasons

\begin{tabular}{ccccccccccc}
\hline Year & $\begin{array}{c}\mathrm{pH} \\
\left(1: 5 \mathrm{H}_{2} \mathrm{O}\right)\end{array}$ & $\begin{array}{c}\mathrm{T}-\mathrm{N} \dagger \\
(\%)\end{array}$ & $\begin{array}{c}\mathrm{OM} \ddagger \\
\left(\mathrm{g} \mathrm{kg}^{-1}\right)\end{array}$ & $\begin{array}{c}\text { Average } \mathrm{P}_{2} \mathrm{O}_{5} \\
\left(\mathrm{mg} \mathrm{kg}^{-1}\right)\end{array}$ & $\begin{array}{c}\text { CEC\$ } \\
\left(\mathrm{cmol}^{+} \mathrm{kg}^{-1}\right)\end{array}$ & & \multicolumn{3}{c}{ Exchangeable cation $\left(\mathrm{cmol}^{+} \mathrm{kg}^{-1}\right)$} \\
\hline 2014 & 7.45 & 0.34 & 50.15 & 635.09 & 9.26 & & $\mathrm{Na}$ & $\mathrm{Ca}$ & $\mathrm{Mg}$ \\
\hline 2015 & 7.33 & 0.26 & 40.05 & 275.67 & 6.37 & 0.93 & 5.91 & 2.02 & 0.17 \\
\hline Mean & 7.39 & 0.30 & 45.10 & 455.38 & 7.82 & 1.29 & 3.19 & 4.13 & 1.47 \\
\hline
\end{tabular}

$\dagger \mathrm{T}-\mathrm{N}$ : total nitrogen.

¥OM: organic matter

$\S C E C$ : cation exchange capacity

good growth characters, yields and feed value (Ji et al., 2010). According to a previous study, SSH cultivars, including Sordan 79 and Jumbo, were cultivated for evaluating forage yield and quality (Kim et al., 1991). It was observed that Sordan 79 was more resistant to leaf blight compared to that of other hybrids, while Jumbo, Sordan 79 and SX 17 were susceptible to lodging.

The objectives of the present study were to evaluate the effects of distinct sowing dates and cultivars variation on the quantitative and qualitative yield in SSHs. This study may form the basis for further development of improved forage cropping system in CRSK.

\section{MATERIALS AND METHODS}

\section{Description of experimental site}

The field experiments were conducted between April 2014 and October 2015 at an upland field in Cheonan (latitude $36^{\circ} 49^{\prime} 0$ ” N l longitude $127^{\circ} 10^{\prime} 0$ ” E), the central reign of South Korea. The conditions of the upland field experiment were clay loam soil which was slightly alkaline ( $\mathrm{pH}$ 7.39), contained higher extractable $\mathrm{K}$ and $\mathrm{P}$ content $\left(1.29 \mathrm{cmol}^{+} \mathrm{kg}^{-1}\right.$ and $355.38 \mathrm{mg} \mathrm{kg}^{-1}$, respectively) and rich in organic matter $\left(45.10 \mathrm{~g} \mathrm{~kg}^{-1}\right)$. The nitrogen and phosphate contents were checked from experimental field soil (Table 1). The seasonal rainfall was $861 \mathrm{~mm}$ in 2014 and $625 \mathrm{~mm}$ in 2015, which was lower than the 30-year precipitation average of $1,066 \mathrm{~mm}$ (Fig. 1). The average air temperature from
April to September was similar to the 30-year mean air temperature; however, they were higher in May 2014 and 2015 (Fig. 2).

\section{Agronomic practices}

Experiments were conducted in a split-split plot design in four factors with three replicates. The main plots consisted of four planting dates (April 20, May 10, May 30 and June 20) and the sub-plots consisted of three SSHs (Jumbo, Sordan 79 and Revolution). Application rates of chemical fertilizers were nitrogen (N) $250 \mathrm{~kg} \mathrm{ha}^{-1}$, phosphate $\left(\mathrm{P}_{2} \mathrm{O}_{5}\right) 150 \mathrm{~kg} \mathrm{ha}^{-1}$ and potassium (potash, $\mathrm{K}_{2} \mathrm{O}$ ) $150 \mathrm{~kg} \mathrm{ha}^{-1}$ each year. Approximately $\mathrm{N}$ fertilizer was applied $40 \%$ on the seeding date, $30 \%$ at the five-leaf stage, and 30\% immediately after the first cutting time. $\mathrm{P}_{2} \mathrm{O}_{5}$ and $\mathrm{K}_{2} \mathrm{O}$ fertilizer applied as the basis of fertilizer. SSHs were planted at the rate of $40 \mathrm{~kg}$ seed per ha and the plot size of each experimental unit was designed as $12 \mathrm{~m}^{2}(3 \mathrm{~m} \times 4 \mathrm{~m})$ with row spacing of $50 \mathrm{~cm}$.

\section{Measurements of dry matter yield}

The harvestable plants were cut down at $15 \mathrm{~cm}$ above the ground level for biomass yield measurement when $50 \%$ of the plants were at the flowering stage. Sub-samples were randomly selected from the harvested crops and dried at approximately $65-70^{\circ} \mathrm{C}$ for $72 \mathrm{~h}$ to determine the percentage of dry matter content.

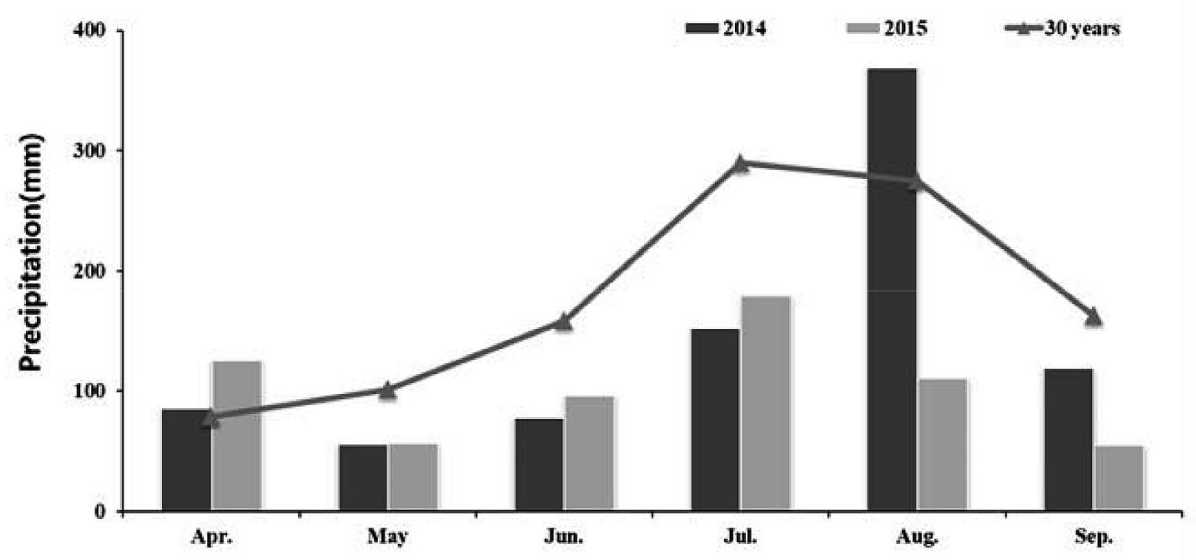

Fig. 1. Mean values of the amount of precipitation during the growing season and 30 years average in Cheonan, Korea, 2014 to 2015. 


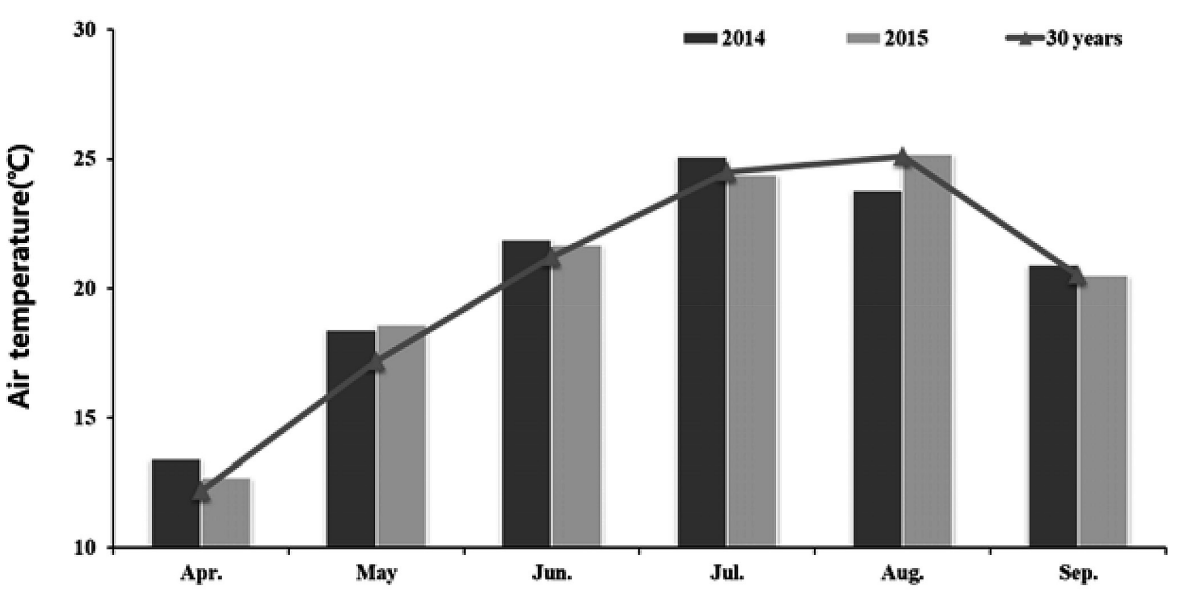

Fig. 2. Mean values of air temperature during the growing season and 30 years average in Cheonan, Korea, 2014 to 2015.

\section{Evaluation of agronomic traits and nutritive val- ues}

Plant height measured from above the soil to the tallest leaf was determined from the harvestable crops, among which ten plants were selected for determination of stem diameter (mm) measured by vernier calipers (Mitutoyo, Japan). Sugar content was measured using a digital refractometer (Atago, Tokyo, Japan) and expressed as ${ }^{\circ}$ Brix. All the agronomic traits were examined with the cooperation of standard research and investigation team (RDA, 2012).

Total crude protein contents were analyzed using the AOAC method (1995). Acid detergent fiber (ADF) and neutral detergent fiber (NDF) were analyzed by Goering and Van Soest method (1991). In vitro dry matter digestibility (IVDMD) was analyzed by the procedure of Moore (1970). Total digestible nutrients (TDN) was calculated by the formula TDN $(\%)=88.9-(0.79 \times$ ADF\%) (Holland, 1990).

\section{Statistical analysis}

Statistical analyses were performed using SAS system v.9.2 (SAS Institute. Inc. Cary, NC, USA). Two-factorial field experiments were conducted according to the randomized split-plot design with three independent replications. Data were analyzed using PROC GLM and means were separated on the basis of Duncan's multiple range test $(p \leq 0.05)$.

\section{RESULTS}

\section{Agronomic characteristics of sorghum $\times$ sudan- grass hybrid}

The heading dates varied due to the variation in seeding date. Plants seeded on April 20 had longer growing period than those on other seeding dates due to cold weather during the early growing season (April) in both years. However, heading dates were no significant difference between Sordan 79 and Revolution. This is probably due to the fact that Sordan 79 and Revolution both were medium maturity cultivars (Table 2).
In this study, plant growth rates were significantly affected by temperature. Lower growth rates were observed in early planting (April 20 and May 10), while the growth rate increased sharply in the delayed planting batch (Fig. 3). Plant height was strongly influenced by planting date and cultivars; the greatest plant height was observed in May 10 planting compared to that of the other planting dates in the first cutting time. In the second cutting time, plant height was higher at early planting (April 20 and May 10), while it reduced sharply after May 10 (Table 3). Among the three hybrid cultivars (Jumbo, Sordan 79, and Revolution), Jumbo was tallest $(268 \mathrm{~cm})$ compared to that of Sordan $79(259 \mathrm{~cm})$ and Revolution $(259 \mathrm{~cm})$ at the first cutting time (Table 3$)$.

In this study, stem diameters were strongly correlated to the sowing dates and cultivars. In the first cutting time, stem diameter was higher in the early sowing date (April 20) and lower in the late planting date compared to those of the other planting dates. As expected, delaying the planting date resulted in reduced stem diameters and the lowest stem diameter was recorded for the cultivars planted on June 20 (Table 3). Stem diameters of Jumbo and Sordan 79 were not significantly different, while Revolution had the smallest stem diameter at the first cutting time. Jumbo showed the thickest stem, followed by Sordan 79 and Revolution, respectively (Table 3).

In the present study, the sugar content was similar among the four planting dates in the first cutting time, except for May 30, which was lower than that of the other planting dates (Table 3). This could be due to constant rains for 3 days prior to harvesting. Among the three hybrid cultivars, Jumbo had significantly the lowest sugar content $\left(3.15^{\circ} \mathrm{Bx}\right)$ in comparison to Sordan 79 $\left(4.80{ }^{\circ} \mathrm{Bx}\right)$ and Revolution $\left(6.52^{\circ} \mathrm{Bx}\right)$ in the first cutting time. The second cutting time was also similar to the first cutting time, thereby the highest sugar content was found for Revolution $\left(7.55^{\circ} \mathrm{Bx}\right)$ and the lowest for Jumbo $\left(4.63^{\circ} \mathrm{Bx}\right)$. 
Table 2. Sowing date, day to heading, harvest date and growing period of sorghum $\times$ sudangrass hybrids a Cheonan, Korea, during the growing season from 2014 to 2015

\begin{tabular}{|c|c|c|c|c|c|c|c|c|c|}
\hline \multirow{2}{*}{ Year } & \multirow{2}{*}{$\begin{array}{l}\text { Sowing } \\
\text { date }\end{array}$} & \multirow{2}{*}{ Cultivars } & \multicolumn{2}{|c|}{ Days to heading } & \multicolumn{2}{|c|}{ Harvest date } & \multicolumn{3}{|c|}{ Growing period (Days) } \\
\hline & & & 1 st & 2nd & 1 st & 2nd & 1 st & 2nd & Total \\
\hline \multirow{12}{*}{2014} & \multirow{3}{*}{ April 21} & Jumbo & - & - & \multirow{3}{*}{ Jul. 16} & \multirow{3}{*}{ Sep. 22} & \multirow{3}{*}{87} & \multirow{3}{*}{68} & \multirow{3}{*}{155} \\
\hline & & Sordan79 & 81 & 62 & & & & & \\
\hline & & Revolution & 85 & 64 & & & & & \\
\hline & \multirow{3}{*}{ May 14} & Jumbo & - & - & \multirow{3}{*}{ Jul. 21} & \multirow{3}{*}{ Sep. 22} & \multirow{3}{*}{61} & \multirow{3}{*}{63} & \multirow{3}{*}{124} \\
\hline & & Sordan79 & 59 & 57 & & & & & \\
\hline & & Revolution & 60 & 61 & & & & & \\
\hline & \multirow{3}{*}{ May 29} & Jumbo & - & - & \multirow{3}{*}{ Aug. 5} & \multirow{3}{*}{ Oct. 1} & \multirow{3}{*}{68} & \multirow{3}{*}{57} & \multirow{3}{*}{131} \\
\hline & & Sordan79 & 66 & 54 & & & & & \\
\hline & & Revolution & 66 & 57 & & & & & \\
\hline & \multirow{3}{*}{ June 20} & Jumbo & - & - & \multirow{3}{*}{ Sep. 4} & \multirow{3}{*}{ Oct. 1} & \multirow{3}{*}{81} & \multirow{3}{*}{27} & \multirow{3}{*}{103} \\
\hline & & Sordan79 & 76 & - & & & & & \\
\hline & & Revolution & 79 & - & & & & & \\
\hline & & Jumbo & - & - & & & & & \\
\hline & April 22 & Sordan79 & 77 & 54 & Jul. 10 & Sep. 2 & 79 & 54 & 133 \\
\hline & & Revolution & 75 & 54 & & & & & \\
\hline & & Jumbo & - & - & & & & & \\
\hline & May 9 & Sordan79 & 65 & 55 & Jul. 15 & Sep. 8 & 67 & 55 & 122 \\
\hline & & Revolution & 65 & 53 & & & & & \\
\hline 2015 & & Jumbo & - & - & & & & & \\
\hline & May 29 & Sordan79 & 65 & 50 & Aug. 4 & Sep. 24 & 67 & 51 & 118 \\
\hline & & Revolution & 65 & 52 & & & & & \\
\hline & & Jumbo & - & - & & & & & \\
\hline & June 19 & Sordan79 & 57 & - & Aug. 17 & Sep. 24 & 59 & 38 & 97 \\
\hline & & Revolution & 57 & - & & & & & \\
\hline
\end{tabular}

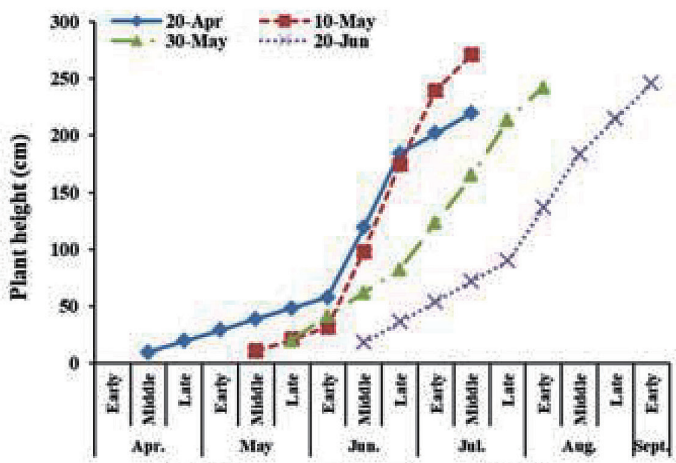

[A] First cutting time (2014)

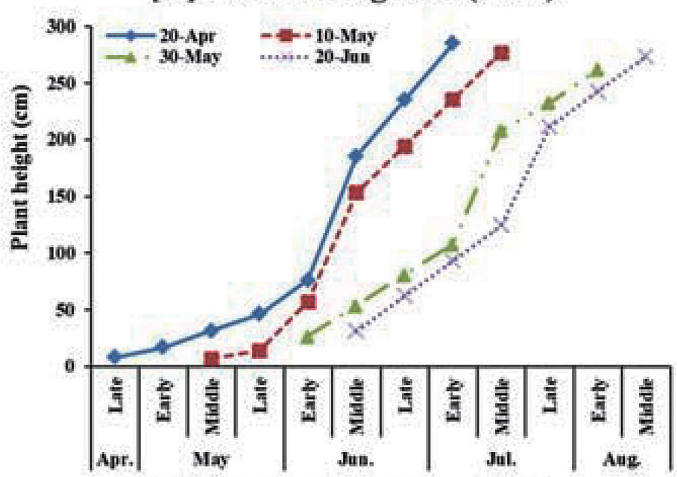

[C] First cutting time (2015)

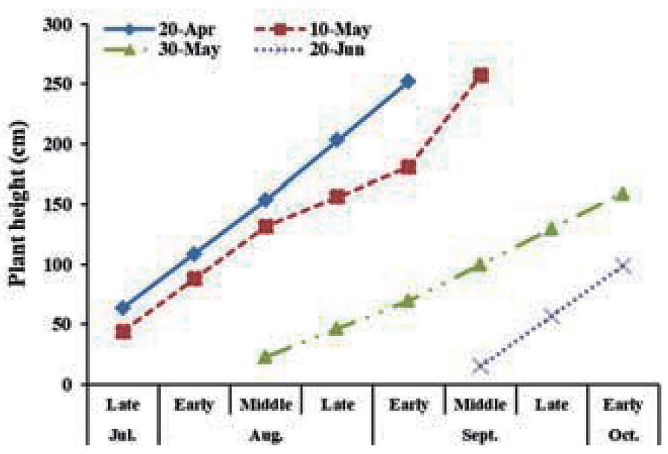

[B] Second cutting time (2014)

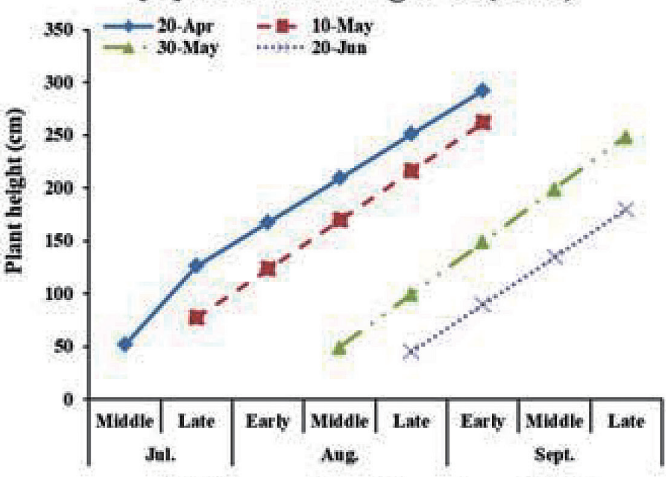

[D] Second cutting time(2015)

Fig. 3. Effects of sowing dates on growth rate of sorghum $\times$ sudangrass hybrids a Cheonan, Korea, during the growing season from 2014 to 2015. 
Table 3. Effects of sowing dates and cultivar variation on plant height, stem diameter and sugar content of sorghum $\times$ sudangrass hybrids at Cheonan, Korea, during the growing seasons from 2014 to 2015

\begin{tabular}{|c|c|c|c|c|c|c|}
\hline \multirow{2}{*}{ Item } & \multicolumn{2}{|c|}{ Plant height } & \multicolumn{2}{|c|}{ Stem diameter } & \multicolumn{2}{|c|}{ Sugar content } \\
\hline & $1 \mathrm{st}$ & 2nd & $1 \mathrm{st}$ & 2nd & 1st & 2nd \\
\hline & & $\ldots$ & & & ........... & \\
\hline \multicolumn{7}{|l|}{ Main effect } \\
\hline 20 April & $262^{\mathrm{b}}$ & $265^{\mathrm{a}}$ & $11.93^{\mathrm{a}}$ & $9.29^{\mathrm{a}}$ & $4.92^{\mathrm{a}}$ & $7.36^{\mathrm{a}}$ \\
\hline 10 May & $274^{\mathrm{a}}$ & $260^{\mathrm{a}}$ & $10.62^{\mathrm{b}}$ & $9.10^{\mathrm{a}}$ & $5.62^{\mathrm{a}}$ & $7.16^{\mathrm{a}}$ \\
\hline 30 May & $252^{\mathrm{c}}$ & $203^{\mathrm{b}}$ & $9.93^{\mathrm{c}}$ & $8.13^{\mathrm{b}}$ & $3.56^{\mathrm{b}}$ & $6.70^{\mathrm{b}}$ \\
\hline 20 June & $260^{\text {bc }}$ & $139^{c}$ & $9.12^{\mathrm{d}}$ & $7.64^{c}$ & $5.30^{\mathrm{a}}$ & $4.46^{c}$ \\
\hline \multicolumn{7}{|l|}{ Subplot effect } \\
\hline Jumbo & $268^{\mathrm{a}}$ & $224^{\mathrm{a}}$ & $10.88^{\mathrm{a}}$ & $9.06^{\mathrm{a}}$ & $3.15^{\mathrm{c}}$ & $4.63^{c}$ \\
\hline Sordan 79 & $259^{\mathrm{b}}$ & $219^{\mathrm{a}}$ & $10.43^{\mathrm{a}}$ & $8.72^{\mathrm{b}}$ & $4.89^{\mathrm{b}}$ & $7.08^{\mathrm{b}}$ \\
\hline Revolution & $259^{\mathrm{b}}$ & $207^{\mathrm{b}}$ & $9.90^{\mathrm{b}}$ & $7.83^{c}$ & $6.52^{\mathrm{a}}$ & $7.55^{\mathrm{a}}$ \\
\hline Main effect (A) & $* * *$ & $* * *$ & $* * *$ & $* * *$ & $* * *$ & $* * *$ \\
\hline Subplot effect(B) & $*$ & $* *$ & $* *$ & $* * *$ & $* * *$ & $* * *$ \\
\hline $\mathrm{A} \times \mathrm{B}$ & ns & ns & ns & ns & $*$ & $* * *$ \\
\hline
\end{tabular}

Means with the same letter in a column for each planting date are not significantly different at the $5 \%$ level, as determined by Duncan's multiple range test. $* \mathrm{p}<0.05 ; * * \mathrm{p}<0.01 ; * * \mathrm{p}<0.001 ;$ ns: Not significant.

\section{Nutritive values of sorghum $\times$ sudangrass hybrid}

In this study, we observed that crude protein (CP) is strongly influenced by planting date and cultivars. The highest $\mathrm{CP}$ was found at May 30 planting date in the first cutting time. In the second cutting time, delaying the planting date resulted in increased $\mathrm{CP}$ content, except for the cultivars sown on May 30. The maximum CP content was obtained for plants sown on June 20 (9.31\%) in the second cutting (Table 4). Among the three hybrid cultivars, Jumbo and Sordan 79 had significantly higher CP content than that of Revolution during both the cutting times.

In this study, we observed that acid detergent fiber $(\mathrm{ADF})$ was similar in all the seeding dates in the first harvest except for May 30, which had the highest ADF content in the second cutting time. In the second harvest, highest $\mathrm{ADF}$ content was noted in the first planting (April 20 - 42.34\%), followed by May 10 (40.35\%), May $30(38.53 \%)$, and June 20 (34.90\%), respectively. Thus, the reduction in $\mathrm{ADF}$ content was induced by delaying the date of planting; this may be due to the cooler and shorter growing period (Table 4). In 2015, no statisti-

Table 4. Effects of sowing dates and cultivar variation on crude protein, acid detergent fiber (ADF), neutral detergent fiber (NDF), In vitro dry matter digestibility (IVDMD) of sorghum $\times$ sudangrass hybrids at Cheonan, Korea, during the growing seasons from 2014 to 2015

\begin{tabular}{|c|c|c|c|c|c|c|c|c|c|}
\hline \multirow{2}{*}{ Item } & \multicolumn{2}{|l|}{$\mathrm{CP}$} & \multicolumn{3}{|l|}{$\mathrm{ADF}$} & \multicolumn{2}{|l|}{$\mathrm{NDF}$} & \multicolumn{2}{|l|}{ IVDMD } \\
\hline & $1 \mathrm{st}$ & 2nd & $1 \mathrm{st}$ & 2nd & & 1 st & 2nd & $1 \mathrm{st}$ & 2nd \\
\hline & & & & ..... & $\%$ & & & & \\
\hline \multicolumn{10}{|l|}{ Main effect } \\
\hline 20 April & $7.33^{\mathrm{b}}$ & $5.92^{\mathrm{d}}$ & $40.68^{\mathrm{a}}$ & $42.34^{\mathrm{a}}$ & & $64.91^{\mathrm{a}}$ & $61.91^{\mathrm{a}}$ & $65.64^{\mathrm{a}}$ & $64.50^{\mathrm{b}}$ \\
\hline 10 May & $6.79^{\mathrm{c}}$ & $7.00^{\mathrm{b}}$ & $39.08^{\mathrm{b}}$ & $40.35^{\mathrm{b}}$ & & $59.54^{c}$ & $61.07^{\mathrm{a}}$ & $64.64^{\mathrm{a}}$ & $64.84^{\mathrm{b}}$ \\
\hline 30 May & $8.74^{\mathrm{a}}$ & $6.46^{c}$ & $42.30^{\mathrm{a}}$ & $38.53^{\mathrm{b}}$ & & $65.63^{\mathrm{a}}$ & $60.65^{\mathrm{a}}$ & $62.14^{\mathrm{b}}$ & $66.34^{\mathrm{b}}$ \\
\hline 20 June & $6.65^{\mathrm{c}}$ & $9.31^{\mathrm{a}}$ & $40.84^{\mathrm{a}}$ & $34.90^{\mathrm{c}}$ & & $62.53^{\mathrm{b}}$ & $57.70^{\mathrm{b}}$ & $65.28^{\mathrm{a}}$ & $72.38^{\mathrm{a}}$ \\
\hline \multicolumn{10}{|l|}{ Subplot effect } \\
\hline Jumbo & $7.57^{\mathrm{a}}$ & $7.41^{\mathrm{a}}$ & $42.18^{\mathrm{a}}$ & $40.37^{\mathrm{a}}$ & & $64.36^{\mathrm{a}}$ & $61.93^{\mathrm{a}}$ & $64.02^{\mathrm{a}}$ & $66.33^{\mathrm{a}}$ \\
\hline Sordan 79 & $7.62^{\mathrm{a}}$ & $7.21^{\mathrm{a}}$ & $39.77^{\mathrm{b}}$ & $38.26^{\mathrm{b}}$ & & $62.45^{\mathrm{b}}$ & $58.98^{b}$ & $64.81^{\mathrm{a}}$ & $67.98^{\mathrm{a}}$ \\
\hline Revolution & $6.95^{\mathrm{b}}$ & $6.90^{\mathrm{b}}$ & $40.23^{\mathrm{b}}$ & $38.45^{\mathrm{b}}$ & & $62.65^{\mathrm{b}}$ & $60.10^{\mathrm{b}}$ & $62.45^{\mathrm{a}}$ & $66.74^{\mathrm{a}}$ \\
\hline Main effect (A) & $* * *$ & $* * *$ & $* *$ & $* * *$ & & $* * *$ & $*$ & $*$ & $* * *$ \\
\hline Subplot effect(B) & $*$ & $*$ & $*$ & $*$ & & $* *$ & $*$ & ns & $\mathrm{ns}$ \\
\hline$A \times B$ & $\mathrm{~ns}$ & ns & ns & $\mathrm{ns}$ & & $\mathrm{ns}$ & ns & ns & ns \\
\hline
\end{tabular}

Means with the same letter in a column for each planting date are not significantly different at the $5 \%$ level, as determined by Duncan's multiple range test. $* \mathrm{p}<0.05 ; * * \mathrm{p}<0.01 ; * * * \mathrm{p}<0.001$; ns: Not significan 
cally significant difference in ADF content was observed in both cutting times; the highest $\mathrm{ADF}$ content (1st $42.18 \%$, 2nd 40.37\%) was observed in Jumbo followed by Revolution (1st 40.23\%, 2nd 38.45\%) and Sordan 79 (1st 39.77\%, 2nd 38.26\%) in both cutting times.

Neutral detergent fiber (NDF) contents were influenced by seeding date and cultivars of SSH. In the first harvest, both for April 20 and May 30, NDF contents were $64.91 \%$ and $65.63 \%$, higher than those for other seeding dates of SSH (2-year average). In the second cutting time, June 20 (57.70\%) was lower in NDF content than that for April 20 (61.91\%), May 10 (61.07\%), and May 30 (60.65\%) planting dates of SSH (2-year average). In three SSHs, the highest NDF content was obtained in Jumbo and there were no significant difference between Sordan 79 and Revolution in the NDF content in the both cutting time (Table 4).

In vitro dry matter digestibility (IVDMD) was strongly influenced by the sowing date. We observed that IVDMD was similar in all the planting dates in the first harvest, expect for May 30, which was lower in IVDMD concentration (62.14\%) than that of the other sowing dates. In the second harvest, delayed planting increased the digestible dry matter. However, the highest IVDMD concentration (72.38\%) was found for June 20 (Table 4). IVDMD content showed no statistically significant differences among the hybrid cultivars.

\section{Dry matter yield of sorghum $\times$ sudangrass hybrid}

Total dry matter yield of SSH was significantly influenced by the sowing date and cultivars. In this study, dry matter yield was noted in the following order: April $20\left(30,249 \mathrm{~kg} \mathrm{ha}^{-1}\right)$, May $10\left(26,921 \mathrm{~kg} \mathrm{ha}^{-1}\right)$, May 30 $\left(20,585 \mathrm{~kg} \mathrm{ha}^{-1}\right)$ and June $20\left(16,461 \mathrm{~kg} \mathrm{ha}^{-1}\right)$ at the $2-$ year average (Fig. 4). Dry matter yield of SSH was reduced for the delayed planting while dry matter yield of SSH was obtained at $16,461 \mathrm{~kg} \mathrm{ha}^{-1}$ from the planting on June 20. Total dry matter yield was 54\% at April 20 planting that was higher than that of the June 20 planting (Fig. 4). In the first cutting time, dry matter yield of SSH was the highest in the earliest planting (April 20) and lowest in delayed planting (June 20). In the cultivars, total dry matter yield of SSH was higher in Jumbo $\left(23,879 \mathrm{~kg} \mathrm{ha}^{-1}\right)$, followed by Sordan $79\left(24,101 \mathrm{~kg} \mathrm{ha}^{-1}\right)$ and Revolution $\left(22,683 \mathrm{~kg} \mathrm{ha}^{-1}\right)$ in the 2-year average (Fig. 4).

\section{DISCUSSION}

The heading dates varied due to the variation in planting date, which was influenced by temperature and day length. The number of days for heading was negatively correlated with temperature and growth period. Pinthus and Resenblum (1961) reported that planting sorghum when soil-surface temperatures were below 18 ${ }^{\circ} \mathrm{C}$ resulted in poor seedling stands because of slow emergence rate and reduced growth rate after germination. As shown the results, increasing growing period of SSH was related with low temperature during the early growing season ( Lee et al., 1997; Thao et al., 2015).

Plant height is considered a good indicator of performance of forage crops, including sorghum (Ali et al., 2014). Pale et al. (2003) and Burks et al. (2013) indicated that the plant height was reduced due to the

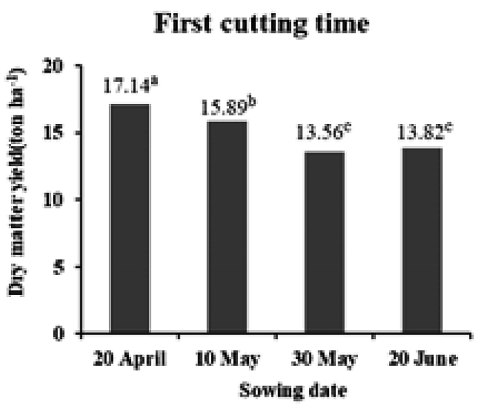

First cutting time

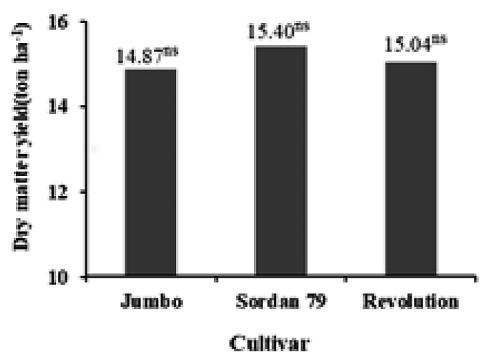

Second cutting time

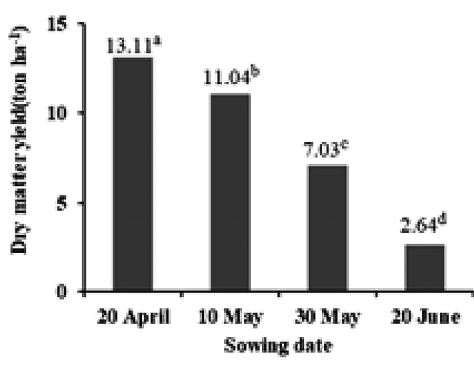

Second cutting time

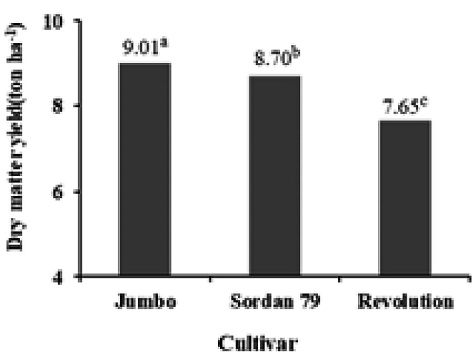

Total dry matter yield

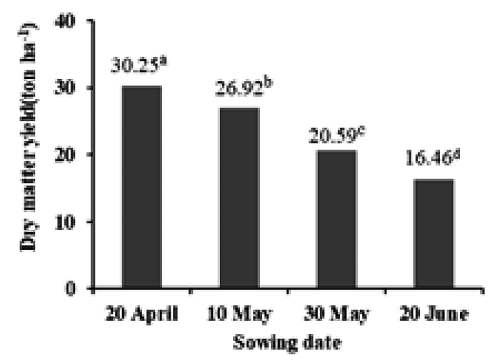

Total dry matter yield

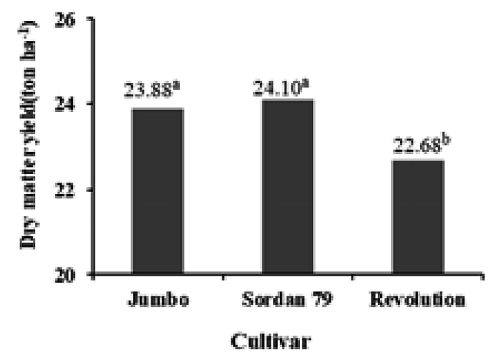

Fig. 4. Comparison of dry matter yield according to seeding dates and cultivar of sorghum $\times$ sudangrass hybrids at Cheonan, Korea, during the growing seasons from 2014 to 2015.

Means with the same letter in a column for each planting date are not significantly different at the $5 \%$ level, as determined by Duncan's multiple range test. 
shorter growing season and low temperatures. In this study, plant height was strongly influenced by seeding date and cultivars. Shin et al. (2015) has reported that plant height decreased with delaying seeding date and plant height was strongly influenced by temperature. Shin et al. (2015), Kim et al. (2012) and Choi et al. (2017) have reported that plant height was not strongly influenced by maturity of cultivars. However, Hwang et al. (2017) have showed that middle maturing cultivars had significantly higher plant height than late maturing cultivars. Also, the results of this experiment are consistent with the findings of Hwang et al. (2017). But, it needs to be interpreted cautiously, because other environmental factors can affect plant height.

We observed that the sugar content of harvested cultivars was strongly influenced by cultivars than seeding dates. In the present study, the sugar content was similar among the four planting dates in the first cutting, except for May 30, which was lower than that of the other planting dates (Table 3). Previous studies have suggested that the juice content depends on stem moisture and sugar content which declined during the rainy season (Maheshwarl et al., 1974; Mecann et al., 2014). Other many reports support that BMR (brown mid-rib) of SSH has more sugar contents than other varieties (Choi et al., 2017; Ji et al., 2010; Kim et al., 2012).

The stem diameter is an important determinant of sorghum productivity (Ji et al., 2010; Tsuchihashi and Goto, 2004). According to Thao et al. (2015), the affected percentage from stem border strongly depended on the environmental conditions with inextricably linked to the sowing time. In this study, stem diameters were strongly correlated to the sowing dates and cultivars. These results indicate that the early sowing date would be useful to obtain thick stem diameters in both the cutting times.

The contents of CP, ADF, NDF, and IVDMD are considered as important physiological indices for forage quality measurement (Van Soest et al., 1991; Moore, 1970). According to Shin et al. (2014), the content of CP was increased by delaying the date of planting; $\mathrm{ADF}$ and NDF were decreased by delaying the date of planting. Also, the contents of $\mathrm{CP}, \mathrm{ADF}, \mathrm{NDF}$ were strongly influenced by cultivars (Ji et al., 2010; Kim et al., 2002; Choi et al., 2017). As a result, it is clear that the contents of $\mathrm{CP}, \mathrm{NDF}$ and ADF were strongly correlated to the seeding date and cultivars.

The total dry matter yield of SSH was significantly influenced by seeding date and cultivars. However, the highest dry matter yield of SSH was found at early seeding (Aril 20) in the first cutting time, while the lowest in delayed seeding (June 20). A previous study has suggested that high dry matter yield of SSH was induced by earlier seeding (April and May). Lee et al. (1997) also reported that total dry matter yield was the highest for May $20\left(20,937 \mathrm{~kg} \mathrm{ha}^{-1}\right)$ and the lowest for June 3 $\left(16,040 \mathrm{~kg} \mathrm{ha}^{-1}\right)$ due to relatively shorter period than that of the earlier planting period in the intercropping cultivation research. Our results indicated that April 20 to May 10 was the best time for seeding of the forage
SSH to maximize forage yield and permit harvest twice in CRSK. May 30 was the critical date for seeding of the SSH to allow two harvests. We depended only on the first cutting of the SSH in seeding on June 20 because seeding of the SSH on June 20 showed the lowest dry matter yield, especially at the second cutting time.

This study provides a better understanding of the effects of different seeding dates and cultivar variation on quantitative yield, as well as base information upon which to develop improved forage cropping systems in CRSK.

\section{AUTHOR CONTRIBUTIONS}

Jeong sung Jung conceived of the presented idea, designed the experiment, carried out the experiment, and wrote the manuscript.

Jin-woong Cho conceived of the presented idea and contributed to the analysis of data and to the final version of the manuscript.

Takeo Yamakawa discussed the results and contributed to the final version of the manuscript.

\section{ACKNOWLEDGMENTS}

This work was carried out with the support of "Cooperative Research Program for Agriculture Science \& Technology Development (Project title: Developing a new cultivation technology of summer forage crops, Project No. PJ01028401)" Rural Development Administration, Republic of Korea.

\section{REFERENCES}

Ali H., S. Alkhamisi, S. Nadaf and A. Al-Bakri (2014) Forage productivity of three introduced sorghum $\times$ sudan grass hybrids under irrigation in three arid areas in Oman. Jordan Journal of Agricultural Sciences 10: 716-724

Association of Official Analytic Chemist (1995) Official methods of analysis, $16^{\text {th }}$ edition, Washington

Burks P. S., T. J. Felderhoff, H. P. Viator and W. L. Rooney (2013) The influence of hybrid maturity and planting date on sweet sorghum productivity during a harvest season. Agron J 105: 263267

Choi G. J., S. H. Lee, K. W. Lee, H. J. Ji, T. Y. Hwang and K. Y. Kim 2017 Comparison of Growth Characteristics, productivity and feed values between varieties of sudangrass and sorghum-sudangrass hybrids. J Korean Soc Grassl Forage Sci 37: 92-99. (In Korean)

Clark A. (2008) Managing cover crops profitably. Diane Publishing, USA, 106

Eastin J. (1976) Temperature influence on sorghum yield. In: Proceedings of the Annual Corn and Sorghum Research Conference

Ejeta G. and J. E. Knoll (2007) Marker-assisted selection in sorghum. Genomics-assisted crop improvement. Springer 187-205

Holland C. and W. Kezar (1990) Pioneer forage manual: a nutritional guide. Pioneer Hi-Bred International

Hwang T. Y., H. C. Ji, K. Y. Kim, S. H. Lee, K. W. Lee, K. S. Kim and G. J. Choi (2017) Agronomic characteristics of sorghum x sudangrass hybrid 'Cadan 99B' and 'Sweet Sioux WMR' in middle and southern region of Korea. J Korean Soc Grassl Forage Sci 37: 254-263. (In Korean)

Ji H. C., S. H. Lee, S. H. Yoon, O. D. Kwon, G. J. Choi, W. H. Kim, K. Y. Kim and Y. C. Lim (2010) Growth, forage production and 
quality of sorghum, sorghum $\times$ sudangrass and sudangrass hybrids at paddy field in southern region of Korea. J Korean Soc Grassl Forage Sci 30: 109-114. (In Korean)

Jung G. H., J. E. Lee, J. H. Seo, S. L. Kim, D. W. Kim, J. T. Kim, T. Y. Hwang and Y. U. Kwon (2012) Effects of seeding dates on harvesting time of double cropped waxy corn. Korean J Crop Sci 57: 195-201. (In Korean)

Kang S. J. (2015) Climate change and its impacts on health policy in Korea. Recent Advances on Environmental and Life Science.

Kim D. A., J. R. Kim, C. H. Kwon, W. H. Kim and J. K. Kim (1991) Performance of sudangrass, sudangrass hybrids and sorghumsudangrass hybrids for forage production, 5; Comparison of recommended cultivars of sorghum-sudangrass hybrids. J Korean Soc Grassl Forage Sci 11: 258-263. (In Korean)

Kim D. J., J. H. Roh, J. G. Kim and J. I. Yun (2013) The influence of shifting planting date on cereal grains production under the projected climate change. Korean J Agric For Meteorol 15: 26-39. (In Korean)

Kim J. D., K. H. Ko and C. H. Kwon (2012) Effect of heading and BMR types on the agronomic characteristics, forage yield and quality of sorghum x sudangrass hybrid. J Korean Soc Grassl Forage Sci 32: 293-300. (In Korean)

Kim J. D., C. H. Kwon, H. J. Kim, J. G. Park, B. S. Lee, G. S. Bing and S. T. Moon (2002) Comparison of agronomic characteristics, forage yield and quality of sorghum x sudangrass hybrid. $J$ Korean Soc Grassl Forage Sci 22: 297-302. (In Korean)

Kim J. D., C. H. Kwon, J. G. Kim, C. H. Kim, H. K. Roh, Y. M. Yoon and J. K. Lee (2009) Forage production and utilization, $1^{\text {st }}$ ed. Shin Kwang, Seoul, 96. (In Korean)

Laucer J. G., P. R. Carter, T. M. Wood, G. Diezel, D. W. Wiersma, R. E. Rand and M. J. Mlynarek (1999) Corn hybrid response to planting date in the northern corn belt. Agron J 91: 834-839

Lee S. M., Y. W. Ryu and B. T. Jeon (1997) Effect of seeding dates on growth characteristics and dry matter yield at intercropping cultivation of sorghum $\mathrm{x}$ sudangrass hybrid and soybean. $J$ Korean Soc Grassl Forage Sci 17: 177-186. (In Korean)

Lee S. M. 2005 Effect of the cultivation method and cutting time on the growth characteristics, dry matter yield and voluntary intake in sorghum x sudangrass hybrid. J Korean Soc Grassl Forage Sci 25: 7-16. (In Korean)

Maheshwari B., J. Prasad, G. Singh and R. Sharma 1974 Studies on sweet sorghum in India. II. Effect of date of sowing and stage of harvest on yield and quality of sweet sorghum. Proc 40 th Ann Conv Sug tech Assoc India

MeCann M. C., M. S. Buckeridge and N. C. Carpita (2014) Plants and BioEnergy. Adv Plant Bio 84.

Moore, J. E. (1970) Procedure for the two-stage in vitro digestion of forage. In: Nutritional research techniques for domestic and wild animals. Utah Univ. Press, Utah State University (U.S.A). 5501
Pachauri R.K., M. Allen, V. Barros, J. Broome, W. Cramer, R. Christ, J. Church, L. Clarke, Q. Dahe and P. Dasgupta (2014) Climate Change 2014: Synthesis Report. Contribution of Working Groups I, II and III to the Fifth Assessment Report of the Intergovernmental Panel on Climate Change

Pale S., S. C. Mason and T. D. Galusha (2003) Planting time for early-season pearl millet and grain sorghum in Nebraska. Agron J 95: 1047-1053

Park J. H., K. Y. Yoon, S. S. Park, J. H. Noh and J. S. Lee (2011) Establishment of cropping system for organic forage production in middle region of Korea. Kor J Organic Agric. 19: 373-384. (In Korean)

Pinthus M. J. and J. Rosenblum 1961 Germination and seedling emergence of sorghum at low temperatures. Crop Sci 1: 293-296

RDA 2012 Investigation and anlalysis of research and technology in agriculture. Rural Development Administarion, Korea, 935-940. (In Korean)

SAS (2002) Statistical analysis system version 9.2. SAS Institute Inc, Cary, NC.

Schittenhelm S. and S. Schroetter. (2014) Comparison of drought tolerance of maize, sweet sorghum and sorghum-sudangrass hybrids. J Agro Crop Sci 200: 46-53

Seo S. and D. A. Kim (1983) Effect of nitrogen fertilization and cutting management on the carbohydrate reserves, regrowth and dry matter yield of sorghum- sudangrass hybrid (Sorghum bicolor (L.) Moench) for forage production. Korean J Anim Sci 26: 80-87. (In Korean)

Shin C. N., K. H. Ko and J. D. Kim (2015) Effect of different seeding dates on agronomic characteristics and productivity of sudangrass hybrid and oat in cropping after corn for silage in Kyeongbuk. J Korean Soc Grassl Forage Sci 34: 81-86. (In Korean)

Son B. Y., J. T. Kim, S. Y. Song, S. B. Baek, C. K. Kim and J. D. Kim (2009) Comparison of yield and forage quality of silage corns at different planting dates. J Korean Soc Grassl Forage Sci 29 : 179-186. (In Korean)

Thao H. T. B., T. V. Dien and T. D. Xuan (2015) Effect of sowing time on the growth, development and productivity of sweet sorghum. Journal of Sustainable bioenergy systems, 5: 127-135

Tsuchihashi N. and Y. Goto (2004) Cultivation of sweet Sorghum (Sorghum bicolor (L.) Moench) and determination of its harbvest time to make use as the raw material for fermentation, praticied during rainy season in dry land of Indonesia. Plant Prod. Sci. 7: 442-448

Van Soest P. J., J. B. Robertson, B. A. Lewis (1991) Methods for dietary fiber, neutral detergent fiber, and nonstarch polysaccharides in relation to animal nutrition. J. Dairy Sci., 74: 3583-3597

Yoana N., E. John, V. Wilfred and w. David (2010) Forage Sorghum (Sorghum bicolor): Overview and Management1. FLORIDA FORAGE. Florida, 65 